\title{
Efficiency evaluation of customer satisfaction index in e-banking using the fuzzy data envelopment analysis
}

\author{
Aliyar Esmaeili" and Mohamad Sadegh Horri
}

Department of Management, Faculty of Management, Azad University of Arak, Markazi, Iran

\begin{tabular}{l}
\hline C H R O N I C L E \\
\hline Article history: \\
Received Feb 28, 2013 \\
Received in revised format \\
19 September 2013 \\
Accepted 23 October 2013 \\
Available online \\
November 242013 \\
\hline Keywords: \\
Customer Satisfaction Index \\
Efficiency \\
Fuzzy Numbers Theory \\
Fuzzy Data Envelopment Analysis \\
Model \\
E-Banking
\end{tabular}

\section{A B S T R A C T}

\begin{abstract}
E-commerce has created significant opportunities for the corporations to understand the customers' expectations, desired values, to increase their satisfaction and to expand their market share, more efficiently. The most significant activity of e-commerce is in the field of e-banking and financial services. Customer satisfaction index is a concept introduced for evaluating of the service quality in electronic banking. Considering the relative importance of customer satisfaction in e-banking, defining scientific criteria for the assessment of mentioned index is very important. So, a scientific and efficient method is always needed. The purpose of this paper is to use the fuzzy data envelopment analysis (DEA) techniques for evaluating and ranking the efficiency of online customer satisfaction index in eight economic banks in Iran. Here, we first study the fuzzy set theory and the method of traditional DEA in the same model. Next, the relationship between them were developed, which provide the fuzzy DEA model with qualitative data. The SPSS and GAMS software package were employed to analyze the data collected through questionnaires. The results show that three economic banks in terms of customer satisfaction in e-banking were located on the efficiency border and were quite efficient.
\end{abstract}

C 2014 Growing Science Ltd. All rights reserved.

\section{Introduction}

Currently, because of the progress occurred in terms of technology, businesses have switched to electronic transactions. Digital economy is the most popular in the field of the electronic commerce and electronic banking. Companies use the internet and web site can adopt a cost-effective way, which helps them become fast-to-market, fast-to-produce, fast to-deliver and fast-to-service company (Feicheng et al., 2009). Phenomenon of e-banking is one of the e-commerce achievements. Today, ebanking is known all around the world as an inseparable part of e-commerce and has a fundamental role in its implementation. Growing e-commerce in the world and the commerce requires an easy, fast, accurate banking system to transfer financial resources, thus e-banking plays a fundamental role 
in e-commerce. Electronic banking (e-banking) is defined as the automated delivery of new and traditional banking products and services directly to customers through electronic, interactive communication channels (Salehi \& Alipour, 2010). Interactive nature of e-banking provides an opportunity to achieve a deeper understanding of customers. On the other hand, the benefits of ebanking in terms of providing better services to customers and improving productivity index of the banks have been investigated by many researchers in the world. The role of customer satisfaction and service quality in development of banking communications has been especially emphasized in the banking literature (Petridou et al., 2007). Many studies show that in today's competitive world, the success of companies is due to the customer retention and having good relationship with customer (Hsiao, 2009). Blanchard and Galloway (1994) stated that customer satisfaction is the result of a customer's perception of the value received in a transaction or relationship; where value is equal to perceived service quality relative to price and customer acquisition costs ( $\mathrm{Su}, 2004)$. The concept of customer satisfaction plays an important role in the marketing literature. Almost all researchers agree that customer satisfaction is generally assumed to be a significant determinant repeat sales of products and services, positive word-of-mouth, and customer loyalty (Barry \& Terry, 2008). Customer satisfaction is considered as a key ingredient in achieving superiority and as an essential role on the success of any organization because it leads to profit ability and customer loyalty to the organization.

Since Oliver (1980) proposed a cognitive model to determine satisfaction, customer satisfaction and customer satisfaction index (CSI) have been widely developed in both theory and applications, especially in the field of marketing, education, medical treatment and guesthouse management (Liu et al., 2008). Established in 1989, the Swedish Customer Satisfaction Barometer (SCSB) was the first truly national customer satisfaction index for domestically purchasing and consuming products and services (Grigoroudis et al., 2008). In developed countries, great efforts have been accomplished in the research and development unit to improve practical understanding customer satisfaction. As an example, we can point out to Fornell described the effective factors in customer satisfaction and found the American Customer Satisfaction Index (ACSI). Later, the European Consumer Satisfaction Index (ECSI) was introduced as an economic indicator, which measures customer satisfaction by an adaptation of the SCSB and the ACSI. Following the public acceptance and understanding the importance of customer satisfaction in Europe and America, many countries have attempted to determine CSI in a national scale; such as SWICS in Switzerland, NCSB in Norway, MCSI in Malaysia and KCSI in Korean (Grigoroudis et al., 2008).

Electronic satisfaction and quality of electronic services are considered as major issues in global electronic commerce and electronic banking. High quality of electronic services is the success key for any corporation that works in global competitive environment of electronic commerce. In the modern management science, the customer satisfaction is considered as a baseline standard of performance and a possible standard of excellence for any business organization (Mihelis et al., 2001). Measuring customer satisfaction has become increasingly popular for the past two decades and today represents an important source of revenue for market research firms. Measuring customer satisfaction offers an immediate, meaningful and objective feedback about clients' preferences and expectations (Gazor et al., 2012). Considering the importance of customer satisfaction index in e-commerce (e-banking), using the scientific criteria for evaluation of mentioned index plays essential role for applying a scientific and efficient method (Liu et al., 2008).

Due to the critical role of customer satisfaction index, analysis of this index is an essential element to discover the strengths and weaknesses of an organization in terms of e-commerce and e-banking. Therefore, efficiency evaluation can significantly help to select the appropriate model and it has been used in the previous works on e-banking from Internet services. A variety of methods have been so far presented by considering several factors to measure customer satisfaction index where each has its own advantages and disadvantages. One of the most useful analysis methods is the Data Envelopment Analysis (DEA). This method is described as a widely used, quantitative and standard tool in 
efficiency measuring studies and is able to provide solutions for better management to achieve the expected output (Cooper et al., 2005). In recent years, the use of qualitative and imprecise data in DEA model is the most important challenge of researchers. One of the options discussed in this context is the use of fuzzy set theory (Wen \& Li, 2009; Zerafat Angiz et al., 2012).

In this study, using fuzzy set theory applications, the possibility of using theoretical data, experiences and human judgments, which are usually qualitative and imprecise, has been applied in the context of DEA model. Fuzzy logic theory is against the Aristotelian binary logic and not only can be used in theory domain, but also is used in industry, which has been involved in various researches. Fuzzy logic theory can be widely used in operation research, management science, control theory and many other fields (Zimmermann, 2010). DEA is a management technique providing a powerful tool for managers to measure their customer satisfaction index compared with other competitors for making better decisions in future. Therefore, in this study, a fuzzy DEA model is used to eliminate the defects in the classical DEA models and to provide the possibility of the measurement of customer satisfaction in e-banking, where data are imprecise and in this way, some useful suggestions on improving customer loyalty are presented.

Here, the fuzzy DEA method based on qualitative data is used for the first time to determine the effectiveness of customer satisfaction index on internet services in e-banking. The organization of this paper is as follows: Some basic concepts of customer satisfaction and studies on customer satisfaction, e-commerce and e-banking and the research model are presented in section 2 . The research methodology is provided in section 3. Section 4 presents the results of data analysis. In the last section (Section 5) a summary of research results and management suggestions for future research are presented.

\section{Literature review and research model}

E-banking is a prerequisite for e-commerce and e-commerce will also further expand with e-banking development. Using e-commerce for achieving the customer satisfaction is considered as the primary driver for the development of modern business firms. The researchers emphasize the importance of customer satisfaction in the banking industry and its indispensable role in maintaining the customer (Farquhar \& Panther, 2008). When an organization can attract a new customer, customer satisfaction will be the starting point to establish a long-term relationship between customer and the organization. Therefore, customer satisfaction is an important factor in determining the quality of provided service and a source of competitive advantage for the organization. Customer satisfaction is post purchase evaluation of a service following a consumption experience (Vasudevan et al., 2006). Dissatisfied customers, on the other hand, are likely to switch brands and engage in negative word of mouth advertisement. Furthermore, behaviors such as repetitive purchase and word-of-mouth directly influence the viability and profitability of a firm (Razak et al., 2007). E-Satisfaction is defined as the contentment of a customer with respect to his/her prior purchasing experience with a given electronic commerce firm (Anderson \& Srinivasan, 2003). Customer satisfaction and loyalty are two dimensions of the most important constructs in relationship e-banking and customer loyalty is the result of customer satisfaction. Customer loyalty is defined as buyer's deeply held commitment to stick with a product, service, brand or organization consistently in the future, despite new situations or competitive overtures to induce switching (Flint et al., 2011). E-loyalty is defined as the customer's favorable attitude toward an electronic business resulting in repetitive buying behavior (Anderson \& Srinivasan, 2003).

Many studies have been conducted on customer satisfaction and e-banking. Numerous examples of these studies are presented as follows. Szymanski and Hise (2000) provided a very interesting model to identify the determinants of electronic satisfaction in online shopping and e-retailing and found that convenience, site design, and financial security display the greatest effect on e-satisfaction. Yang and Fang (2004) determined the online services quality dimensions and showed the relationship 
between these dimensions with customer satisfaction. These qualitative dimensions include: reliability, responsiveness, ease of use, competence. Petridou et al. (2007) in a research on the quality of bank service studied the effect of service quality on customer satisfaction in private banks in Greece and Bulgaria; the results showed that Greece customers had higher levels of service quality perceptions as compared with Bulgarian customers. Molina et al. (2007) surveyed the effect of longterm customer relationships with their bank and satisfaction. Their results showed that an ensured customers' attitude has a significant effect on customer satisfaction of bank. In a recent study, Liu et al. (2008) studied the concept of customer satisfaction index in e-commerce from the viewpoint of system control and system analysis. Poddar et al. (2009) presented a model in which three variables of web site personality, web site quality, and web site customer orientation were identified as factors affecting purchase intentions. Finn (2011) in a research in the field of electronic services, using statistical methods showed that some service quality dimensions have non-linear relationship with customer satisfaction. Considering the importance of customer satisfaction in e-banking and the results of previous researches, the variables which can create different values at different times for internet customers in e-banking explained as follows:

Perceived quality: Perceived quality refers to a consumer's judgment about overall excellence or superiority (Sánchez-Fernández \& Iniesta-Bonillo, 2009). Service quality is the customers' subjective assessment of the expectations with actual service performance (Cheung \& Lee, 2005). Service quality in e-commerce can be defined as the consumers overall evaluation and judgment of the excellence and quality of e-service offerings in the virtual market place (Marimon et al., 2012). Customer satisfaction and loyalty are functions of customer perception about service quality (Lee \& Hwan, 2005).

Perceived value: Perceived value refers to the perceived level of product and service quality relative to the price paid (Ciavolino \& Dahlgaard 2007). Perceived value is often assumed to involve a consumer's assessment of the ratio of perceived benefits to perceived costs (Wang et al., 2012). Customer satisfaction is directly associated with perceived value; when perceived value increases, customer satisfaction also increases.

Customer expectations: Customer expectations refer to the level of quality that customers expect to receive and are the result of prior consumption experience with a firm's products or services (Ciavolino \& Dahlgaard, 2007). According to Zeithaml et al. (2006), customer expectations are beliefs about a service, which serves as standards or reference points in which the performance of the service is judged. Customer expectations are reference points for measuring the received service quality. That is why the variable of customer expectations has a positive impact on customer satisfaction and customer loyalty. In addition, customer expectations have positive and direct impact on perceived quality and perceived value.

Image: the image construct evaluates the underlying image of the company. Image refers to the brand name and the kind of associations customers obtain from the product/company (Ciavolino \& Dahlgaard, 2007). Kristensen et al. (2000) argued that image is an important dimension of the customer satisfaction model. Image is a consequence of being reliable, professional and innovative, having contributions to society, and adding prestige to its user. It is anticipated that image has a positive effect on customer satisfaction, customer expectations and customer loyalty.

Customer satisfaction: Customer satisfaction can be described as customers' evaluations of a product or service with regard to their needs and expectations (Bai et al., 2008). Customer satisfaction is post purchase evaluation of a service following a consumption experience (Vasudevan et al., 2006). Customer satisfaction is an emotional reaction or a state of mutual cognitive understanding (Reynolds \& Harris, 2009). Szymanski and Hise (2000) defined e-satisfaction from the e-commerce perspective, as the measure of satisfaction with the online or web shopping. According to a popular theory in 
marketing literature, the immediate consequence of customer satisfaction increase is due to reduction in his/her complaints and increase customer loyalty (Casado-Díaz \& Nicolau-Gonzálbez, 2009).

Customer loyalty: Customer loyalty has been defined as a deeply held commitment to rebuy or repatronize a preferred product/ service consistently in the future (Davis-Sramek et al., 2009). Cyr et al. (2008) defined e-loyalty, meaning online loyalty, as perceived intention to visit or use web sites and to consider purchasing from them now and later. Wirtz (2003) listed the results of customer satisfaction; repeat purchase; loyalty; positive word-of-mouth and increased long-term profitability.

For using the fuzzy DEA model to determine efficiency of customer satisfaction index from provided internet service in e-banking, the perceived quality, customer expectations, image, perceived value were considered as input variables while customer satisfaction and customer loyalty were considered as output variables (See Fig. 1). To determine the efficiency of customer satisfaction, we converted a fuzzy DEA model to linear programming model using the $\alpha$-cut method. GAMS software was used in this study to design the structure of branches and to evaluate the efficiency of customer satisfaction index from electronic banking services.

Input Variable

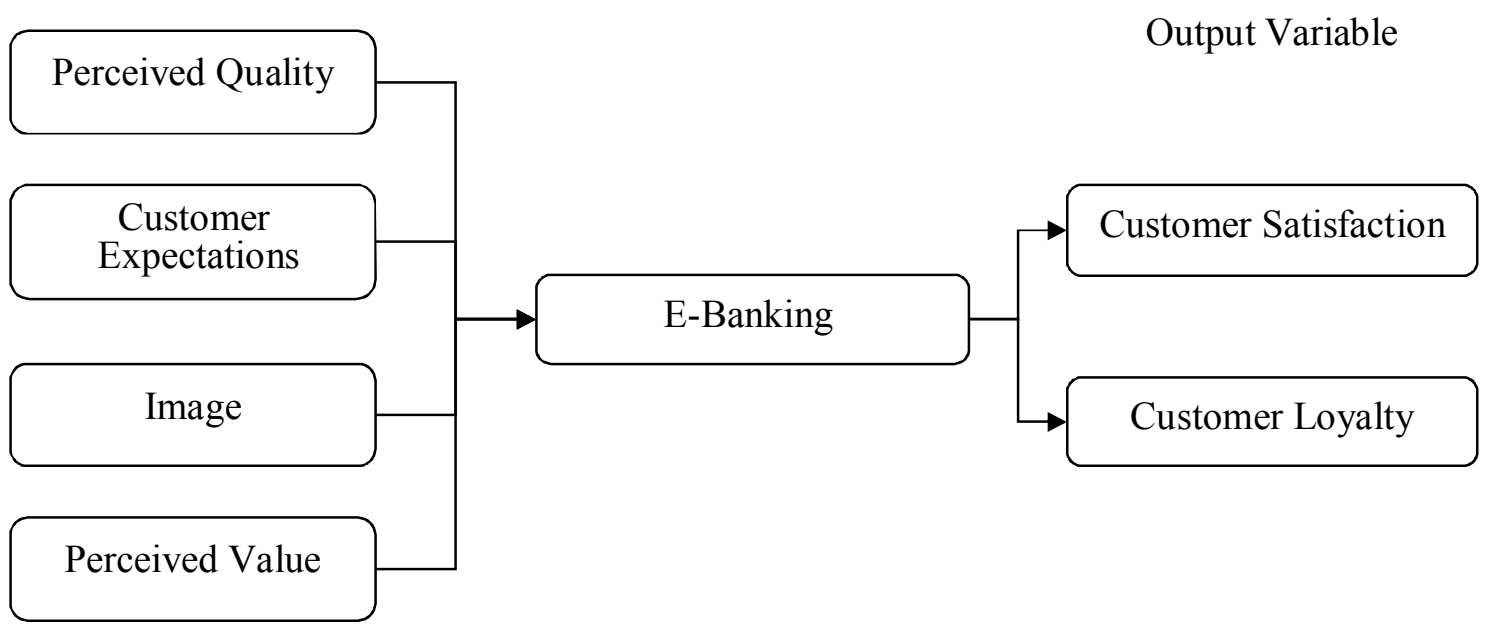

Fig. 1. Fuzzy DEA model related to customer satisfaction index

\section{Methodology}

\subsection{Survey instrument}

Fuzzy DEA model is associated with customer satisfaction index shown in Fig. 1 based on prominent previous researches and theories on customer satisfaction. This model includes some hidden variables, which can be described by a set of observable items. Perceived quality, image, customer expectations, and perceived value are considered as input variables of the model while customer satisfaction and customer loyalty are considered as output variables of the model. These variables and constituent items as presented in Table 1.

Data collection tool was a questionnaire based on mentioned index. This questionnaire included 20 questions adjusted in ordinal and Likert scale including very low, low, medium, high and very high. Validity and reliability are two necessary features for every measuring material such as questionnaire because these materials should analyze data and provide conclusions for researchers.

To ensure the validity of the questionnaire the experts' opinions were used. In addition, Cronbach's alpha coefficient was used to assess the reliability of the questionnaire. In order to test the reliability 
of the questionnaire, 30 questionnaires were collected from a sample and Cronbach's alpha coefficient was calculated using SPSS software. Cronbach's alpha was calculated 0.903 for this questionnaire that showed the high reliability of the questionnaire.

\section{Table 1}

Constituent variables and items related to the model of customer satisfaction index

\begin{tabular}{cl}
\hline \multicolumn{1}{c}{ Variables } & \multicolumn{1}{c}{ Items } \\
\hline Perceived quality & PQ1: General expression of service quality by provided information \\
& PQ2: Tools to compare service with service of competitors \\
& PQ3: Web's ability to meet customer needs \\
PQ4: User-friendliness of the web site in terms of prestige capabilities \\
\hline Customer expectations & EXP1: Having the necessary tools to search for services \\
& EXP2: Matching customer needs with provided service \\
\hline EXP3: Ease of use for searching a service \\
\hline Image & IM1: Adding value to user (prestige) \\
\hline IM2: Being professional \\
\hline Perceived value & PV1: Customers feeling to the uniqueness of the service \\
\hline PV2: Coordination between web site advertising with customer needs \\
\hline PV3: Entertainment feeling during the use of service \\
\hline CS1: Satisfaction of decision to use the service \\
\hline CS2: Satisfaction of rationality of service using \\
\hline CS3: Satisfaction of expectations realization \\
\hline CL1: Being the first selected web site for using a service \\
\hline CL2: Recommending the others to use this web site \\
\hline CL3: Selection of this web site as the best one among the competitors \\
\hline CL4: Faith and belief in the use of service \\
\hline
\end{tabular}

\subsection{Sample and data collection}

Evaluation model of customer satisfaction index efficiency in e-banking was conducted in the second half of 2013, in Iran. Electronic Banking in Iran is developing so rapidly that new banking services have led to intense competition in e-banking industry. In Iran, more than 20 public and private banks are active in the field of electronic banking service. Isfahan is the pioneer center of e-banking and tourism industry in Iran. Population of this study included online customers of eight economic banks in Isfahan. Customers of these banks were pretty active in using the e-banking services in this period of time. Although the estimated required sample numbers for this study were 240, to ensure the efficiency of data, the questionnaires were given to 276 purposefully selected samples. These samples were selected among customers who had enough information about e-banking. Demographically, $64 \%$ of respondents were men, $67 \%$ of respondents were in the age range of 20 to 35 years old and $33 \%$ of respondents were over 35 years old. In terms of education, $53 \%$ of respondents had a bachelor's degree, $31 \%$ had a master's degree or higher and $16 \%$ were students. These statistics showed that the higher the education of people, the higher their tendency to use e-banking.

\subsection{Data envelopment analysis}

A non-parametric method for assessing the decision making units (DMUs) is data envelopment analysis model which has many applications in efficiency evaluation and productivity measurement. The DEA method was first introduced in 1978 by Rhodes in the Carengie Mellon University as a doctoral thesis and was used for assessing the educational progress of national school students in America. The first article of DEA was presented by Charnes et al. (1978) in that year and was known as the CCR model. DEA models assess the ability of each decision making units (DMUs) in converting inputs to outputs. This level of ability calls the efficiency. Efficiency evaluation of one decision making unit (DMUs) in the DEA model requires comparing its outputs with its inputs. The DMUs are characterized by several inputs and outputs. The efficiency score in the midst of multiple input and output factors is defined as (Talluri, 2000). 


$$
\text { Efficiency }=\frac{\text { weighted sum of outputs }}{\text { weighted sum of inputs }}
$$

Banker et al. (1984) provided the basic principles and in addition to reformulation of CCR model according to these principles, designed another model, which was known as BCC model. CCR is adopted to evaluate performances of DMUs under the assumption of constant returns to scale. BCC is used to understand variable returns to scale, including constant, decreasing and increasing. In general, DEA models are divided into both input-orientated and output-orientated. The main objective in input -orientated model is to reduce the inputs so that it can be possible to achieve the same previous outputs, and in output-orientated models, the main objective is to increase the outputs so that the inputs remain stable. Consider a set of $n$ DMUs where $\mathrm{DMU}_{\mathrm{j}}$ consumes $X_{j}=\left(x_{1 j}, x_{2 j}, \ldots, x_{m j}\right)$ inputs and produce $Y_{j}=\left(y_{1 j}, y_{2 j}, \ldots, x_{s j}\right)$ outputs. Suppose $x_{i j}(\mathrm{i}=1,2, \ldots, \mathrm{m})$ is quantity of input $i$ consumed by DMU $\mathrm{j}_{\mathrm{j}}$ and $y_{r j}(\mathrm{r}=1,2, \ldots, \mathrm{s})$ is quantity of output $r$ produced by $\mathrm{DMU}_{\mathrm{j}}$. The outputorientated CCR primal model for $D M U_{p}$ is then written as follows (Charnes et al., 1978):

$$
\begin{array}{ll}
\min & \sum_{i=1}^{m} v_{i} x_{i p} \\
\text { s.t. } & \sum_{\substack{s \\
s=1}}^{s} u_{r} y_{r j}-\sum_{i=1}^{m} v_{i} x_{i j} \leq 0 \quad j=1,2, \ldots, n \\
& \sum_{r=1}^{s} u_{r} y_{r p}=1 \\
& u_{r}, v_{i} \geq \varepsilon>0 \quad i=1,2, \ldots, m ; r=1,2, \ldots, s
\end{array}
$$

In the output-orientated CCR primal model, the objective function value is greater than or equals to 1 . If the objective function value is 1 , it will be the sign of the efficiency of understudy DMU and if this value is more than 1, it will show the inefficiency of DMU (Charnes et al., 1978). Ranking of the different units can orient correctly the analysis and decisions on the efficiency or inefficiency of units, change the inefficient units to efficient ones and for the better conclusions to recognize the importance of one unit situation rather than others. The method of ranking DMUs in this study is called Super-Efficiency Ranking which was presented by Andersen and Petersen (1993). In this method, the efficiency of an efficient DMU is measured compared with the other efficient DMUs. In output-oriented Andersen-Petersen model (AP model), DMUs which have the objective function value of less than 1, will be ranked higher than other DMUs (Andersen \& Petersen 1993). The outputoriented AP model is given as follows:

$$
\begin{array}{ll}
\text { Min } & \sum_{i=1}^{m} v_{i} x_{i p} \\
\text { s.t. } & \sum_{r=1}^{s} u_{r} y_{r j}-\sum_{i=1}^{m} v_{i} x_{i j} \leq 0 \quad j \neq p \\
& \sum_{r=1}^{s} u_{r} y_{r p}=1 \\
& u_{r}, v_{i} \geq \varepsilon>0 \quad i=1,2, \ldots, m ; r=1,2, \ldots, s
\end{array}
$$

\subsection{Fuzzy set theory}

Fuzzy concept was expressed for the first time in Max Black's article called "vagueness" in 1937. Then, in 1965, Lotfi Zadeh, published his article entitled "fuzzy sets" in the Journal of Information 
and Control. Lotfi Zadeh described fuzzy sets as "curves membership". Lotfi Zadeh defined fuzzy sets as the sets with vague and imprecise borders. He expresses this concept as: membership in a fuzzy set is not a definite or indefinite matter, but the membership is expressed as a degree (Zadeh, 1965).

\subsubsection{Fuzzy set}

A fuzzy set $\tilde{A}$ defined on a universe $X$ may be given as:

$$
\tilde{A}=\left\{\left(x, \mu_{\tilde{A}}(x)\right) \mid x \in X\right\},
$$

where $\mu_{\tilde{A}}: X \rightarrow[0,1]$ is the membership function of $\tilde{A}$. The membership value $\mu_{\tilde{A}}(x)$ describes the degree of belongingness of $x \in X$ in $\tilde{A}$ (Zimmermann, 2010).

\subsubsection{Triangular fuzzy number}

A triangular fuzzy number $\tilde{A}$ is defined with piecewise linear membership function $\mu_{\tilde{A}}(x)$ as follow (Li, 2012):

$\mu_{\tilde{A}}(x)=\left\{\begin{array}{cc}0, & x \leq l, \\ \frac{(x-l)}{(m-l)}, & l \leq x \leq m, \\ \frac{(x-u)}{(m-u)}, & m \leq x \leq u, \\ 0, & \text { Otherwise. }\end{array}\right.$

and as a triplet $(l, m, u)$ is indicated where $l, u$ are the lower and upper bounds, respectively, and $m$ is the most likely value of $\widetilde{\mathrm{A}}$. A triangular fuzzy number $\tilde{A}$ can be defined by a triplet $(l, m, u)$ shown in Fig. 2.

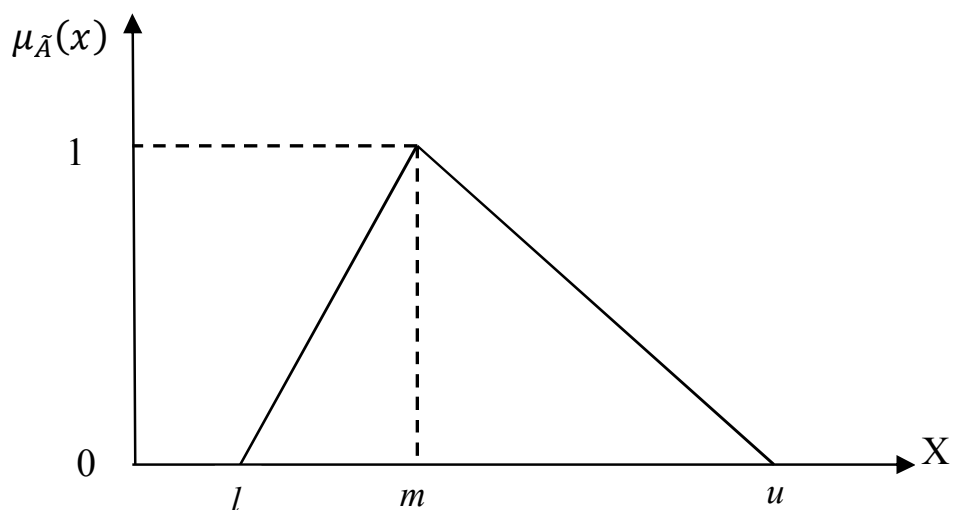

Fig. 2. A triangular membership function, $\mu_{\tilde{A}}(x)$

The main arithmetic operations for two positive triangular fuzzy numbers $\widetilde{M}=(1, m, u)$ and $\tilde{N}=(p, q$, s) are as follows (Li, 2012) :

- Multiplication of any real number $\lambda$ and a fuzzy number,

$\lambda \otimes \widetilde{M}=\lambda \otimes(l, m, u)=(\lambda l, \lambda m, \lambda u) \quad l \geq 0, \lambda \geq 0$.

- $\quad$ Addition of two triangular fuzzy numbers,

$\widetilde{\mathrm{M}} \oplus \widetilde{\mathrm{N}}=(\mathrm{l}+\mathrm{p}, \mathrm{m}+\mathrm{q}, \mathrm{u}+\mathrm{s}) \quad \mathrm{l} \geq 0, \mathrm{p} \geq 0$. 
- $\quad$ Division of two fuzzy numbers,

$\widetilde{\mathrm{M}} \Delta \widetilde{\mathrm{N}}=(\mathrm{l} / \mathrm{p}, \mathrm{m} / \mathrm{q}, \mathrm{u} / \mathrm{s}) \quad \mathrm{l} \geq 0, \mathrm{p} \geq 0$.

- Multiplication of two triangular fuzzy numbers,

$\widetilde{\mathrm{M}} \otimes \widetilde{\mathrm{N}}=(\mathrm{lp}, \mathrm{mq}, \mathrm{us}) \quad \mathrm{l} \geq 0, \mathrm{p} \geq 0$.

- $\quad$ The average triangular fuzzy numbers,

$$
\widetilde{\mathrm{M}}_{\mathrm{AVG}}=\frac{\widetilde{\mathrm{M}}_{1}+\widetilde{\mathrm{M}}_{2}+\cdots+\widetilde{\mathrm{M}}_{\mathrm{n}}}{n}=\frac{\left(\mathrm{l}_{1}, \mathrm{~m}_{1}, \mathrm{u}_{1}\right)+\cdots+\left(\mathrm{l}_{\mathrm{n}}, \mathrm{m}_{\mathrm{n}}, \mathrm{u}_{\mathrm{n}}\right)}{n}=\left(\frac{1}{n} \sum_{i=1}^{n} l_{i}, \frac{1}{n} \sum_{i=1}^{n} m_{i}, \frac{1}{n} \sum_{i=1}^{n} u_{i}\right) \text {. }
$$

$3.4 .3 \alpha-c u t$

An $\alpha$-cut of a fuzzy set $A$ is a crisp set $\mathrm{A}_{\alpha}$ that contains all elements in the universal set $X$ with membership grades in $A$ greater than or equal to a specified value of $\alpha$ stated as ( $\mathrm{Li} 2012$ ),

$$
A_{\alpha}=\left\{x \in X \mid \mu_{\tilde{A}}(x) \geq \alpha\right\}
$$

\subsubsection{Linguistic variable}

Linguistic variables are variables in which the values of words or sentences are expressed in a natural or artificial language. In other words, in a natural language, the variables with imprecise and ambiguous values are used more than the variables with precise and determined values. Usually the evaluators are requested to judge through the language variables of "very low", "low", "medium", "high" and "very high" where it is possible to consider a scale between 0 and 10 using triangular fuzzy numbers. Triangular fuzzy numbers according to Likert scale is given in Table 2.

Table 2

Triangular fuzzy numbers according to Likert scale

\begin{tabular}{llllll}
\hline Likret scale & Very low & Low & Medium & High & Very high \\
\hline Triangular fuzzy number & $(2,2,4)$ & $(2,4,6)$ & $(4,6,8)$ & $(6,8,10)$ & $(8,10,10)$ \\
\hline
\end{tabular}

\subsection{Fuzzy data envelopment analysis}

Most methods of DMUs ranking assume that all inputs and outputs data are precisely known. However, in most general cases, the data for evaluation are often gathered from investigation to Judge the natural language such as good, medium and bad rather than a specific case. For example, customer satisfaction measurement in e-banking and service quality cannot be stated as a definite number. Therefore, DEA models in practice cannot provide good results, so, the necessity of using indefinite numbers or fuzzy numbers in these models will become obvious. Fuzzy DEA is a powerful tool for evaluating the performance of DMUs with imprecise data (or interval data). Sengupta (1992) was the first to introduce a fuzzy mathematical Programming approach where the constraints and objective function are not satisfied crisply. Guo and Tanaka (2001) introduced a fuzzy DEA method to determine the efficiency regarding to the $\alpha$-cut in which data were considered as the symmetrical triangular fuzzy numbers. Saati et al. (2001) developed a fuzzy DEA model, which deals with the infeasibility difficulties of Andersen and Petersen's model. Thus, Saati et al. (2002) presented a model for efficiency analysis and ranking of DMUs with fuzzy data.

\subsubsection{Fuzzy Output-orientated CCR model}

In this study, to measure the customer satisfaction index in e-banking, the fuzzy data is used as input and output variables of output-oriented CCR model. Fuzzy data is considered as triangular numbers 
and the following method is used for solving the fuzzy model and converting it to linear programming model.

Consider the set of DMUs including DMU $\mathrm{D}_{\mathrm{j}}$ with fuzzy inputs and outputs. $\tilde{x}_{i j}=\left(x_{i j}^{l}, x_{i j}^{m}, x_{i j}^{u}\right)$ and $\tilde{y}_{r j}=\left(y_{r j}^{l}, y_{r j}^{m}, y_{r j}^{u}\right)$ are inputs and outputs respectively, and both of them have Triangular property. Existence of the large amount of DMUs causes to the complexity in solving of the equations in the CCR primal model. Therefore, in this study, we used CCR dual model for the better evaluation of the DMUs. The output-orientated CCR dual model is used to maximize the efficiency of DMUs and $\theta$ is efficiency value. Now, considering Output-orientated CCR dual model with fuzzy data as follows:

$\begin{array}{ll}\text { Max } & \theta \\ \text { s.t. } & \sum_{j=1}^{n} \lambda_{j} \tilde{y}_{r j} \geq \theta_{p} \tilde{y}_{r p} \quad r=1,2, \ldots, s, \\ & \sum_{j=1}^{n} \lambda_{j} \tilde{x}_{i j} \leq \tilde{x}_{i p} \quad i=1,2, \ldots, m, \\ & \lambda_{j} \geq 0 \quad j=1,2, \ldots, n\end{array}$

$\tilde{x}_{i j}=\left(x_{i j}^{l}, x_{i j}^{m}, x_{i j}^{u}\right)$ and $\tilde{y}_{r j}=\left(y_{r j}^{l}, y_{r j}^{m}, y_{r j}^{u}\right)$ are the fuzzy input and output variables respectively, the triangular fuzzy numbers can be converted to following crisp intervals using the $\alpha$-cuts:

$$
\left[x_{i j}^{m}-(1-\alpha) x_{i j}^{l}, x_{i j}^{m}+(1-\alpha) x_{i j}^{u}\right] \quad\left[y_{r j}^{m}-(1-\alpha) y_{r j}^{l}, y_{i j}^{m}+(1-\alpha) y_{r j}^{u}\right]
$$

Regarding the fact that the used data in linear programming model is in the form of crisp numbers, after integrating each variable crisp interval, one crisp number will be achieved for each variable. Integration method is expressed as follows:

$$
\begin{aligned}
& R\left(A_{\alpha}\right)=\frac{1}{2} \int_{0}^{1}\left[x_{i j}^{m}-(1-\alpha) x_{i j}^{l}, x_{i j}^{m}+(1-\alpha) x_{i j}^{u}\right] d \alpha=\frac{1}{4}\left(x_{i j}^{l}+2 x_{i j}^{m}+x_{i j}^{u}\right) \\
& R\left(A_{\alpha}\right)=\frac{1}{2} \int_{0}^{1}\left[y_{r j}^{m}-(1-\alpha) y_{r j}^{l}, y_{r j}^{m}+(1-\alpha) y_{r j}^{u}\right] d \alpha=\frac{1}{4}\left(y_{r j}^{l}+2 y_{r j}^{m}+y_{r j}^{u}\right)
\end{aligned}
$$

According to mentioned variable changes fuzzy Output-orientated CCR model can be converted into a linear programming model as follows:

$$
\begin{aligned}
& \operatorname{Max} \theta \\
& \text { s.t. } \quad \sum_{j=1}^{n} \lambda_{j} \hat{y}_{r j} \geq \theta_{p} \hat{y}_{r p} \quad r=1,2, \ldots, s \text {, } \\
& \sum_{j=1}^{n} \lambda_{j} \hat{x}_{i j} \leq \hat{x}_{i p} \quad i=1,2, \ldots, m, \\
& \lambda_{j} \geq 0 \quad j=1,2, \ldots, n
\end{aligned}
$$

\subsubsection{Fuzzy Output-orientated Andersen-Petersen model}

There are several methods for ranking of DMUs. One of the methods for ranking DMUs is AP model. The super-efficiency model of Andersen and Petersen (1993) is used to score hotels that were included in the CCR-Efficient set. The Output-orientated AP model with fuzzy data is as follows: 


$$
\begin{array}{ll}
\text { Max } & \theta \\
\text { s.t. } & \sum_{\substack{j=1 \\
j \neq p \\
n}}^{n} \lambda_{j} \tilde{y}_{r j} \geq \theta_{p} \tilde{y}_{r p} \quad r=1,2, \ldots, s, \\
& \sum_{\substack{j=1 \\
j \neq p}}^{n} \lambda_{j} \tilde{x}_{i j} \leq \tilde{x}_{i p} \quad i=1,2, \ldots, m, \\
& \lambda_{j} \geq 0 \quad j=1,2, \ldots, n
\end{array}
$$

\section{Analysis and findings}

Each technique or model has its own analysis method in which we can analyze the data. In this study, for evaluating and measuring the customer satisfaction index in e-banking, output-orientated CCR model with triangular fuzzy numbers was used which can then cause an increase in customer satisfaction and loyalty. With considering the fuzzy data, the standard CCR model will in fact, convert to a fuzzy linear programming. According to $\alpha$-cut method, fuzzy linear programming will convert to a definitive linear programming, which can be solved by GAMS software. The important point in determining the efficiency and productivity of e-banking is the respect to the multi-role nature of customer satisfaction index. For efficiency evaluation and performance measurement of this index, we should consider several inputs and outputs. Perceived quality, image, customer expectations and perceived value were considered as the input variables while customer satisfaction and customer loyalty were considered as output variables in evaluation model of customer satisfaction index efficiency in e-banking. 30 internet customers of each bank were considered as samples of related bank. After the data collection through the questionnaires and conversion of answers (Likert scale) to the triangular fuzzy numbers, the fuzzy average method was used to determine the final fuzzy values of the variables. At first, the fuzzy average of each person's comments about variables was calculated, then, the fuzzy average of all comments of selected sample from each bank was calculated. The results are given in Table 3.

\begin{tabular}{|c|c|c|c|c|c|c|}
\hline Bank & $\begin{array}{c}\text { Perceived quality } \\
\text { input variable }\end{array}$ & $\begin{array}{c}\text { customer } \\
\text { input variable }\end{array}$ & $\begin{array}{c}\text { Image } \\
\text { input variable }\end{array}$ & $\begin{array}{l}\text { perceived value } \\
\text { input variable }\end{array}$ & $\begin{array}{c}\text { customer } \\
\text { input variable }\end{array}$ & $\begin{array}{c}\text { customer loyalty } \\
\text { input variable }\end{array}$ \\
\hline Pasargad bank & $(4.7,6.7,8.7)$ & $(5.2,7.1,8.9)$ & $(5.2,7.1,8.9)$ & $(4.5,6.4,8.3)$ & $(6.1,8,9.4)$ & $(6.1,8,9.5)$ \\
\hline Ansar bank & $(3.73,5.73,7.73)$ & $(4.22,6.13,8.08)$ & $(4.22,6.08,8.04)$ & $(4.18,6.04,8.04)$ & $(5.42,7.42,9.2)$ & $(5.13,7.13,8.9)$ \\
\hline Parsian bank & $(5.04,7.04,8.91)$ & $(5.02,7.02,8.57)$ & $(5.34,7.34,9.11)$ & $(4.84,6.84,8.7)$ & $(5.1,7.1,8.97)$ & $(4.9,6.9,8.76)$ \\
\hline Saman bank & $(4.9,6.9,8.9)$ & $(4.61,6.61,8.61)$ & $(4.45,6.45,8.45)$ & $(4.58,6.58,8.58)$ & $(5.96,7.96,9.63)$ & $(5.83,7.83,9.56)$ \\
\hline Shahr bank & $(4.77,6.77,8.76)$ & $(4.80,6.80,8.76)$ & $(4.71,6.71,8.66)$ & $(4.18,6.18,8.18)$ & $(4.08,6.08,8.08)$ & $(4.3,6.3,8.07)$ \\
\hline Eghtesad-Novin & $(4.73,6.7,8.6)$ & $(4.58,6.58,8.58)$ & $(4.76,6.76,8.71)$ & $(4.62,6.62,8.62)$ & $(4.43,6.43,8.43)$ & $(4.3,6.3,8.26)$ \\
\hline Sarmayeh bank & $(5.13,7.13,9.0)$ & $(5.45,7.45,9.14)$ & $(5.32,7.32,9.24)$ & $(5.14,7.14,9.0)$ & $(4.89,6.89,8.84)$ & $(4.76,6.76,8.7)$ \\
\hline Tose'e bank & $(4.96,6.96,8.9)$ & $(4.85,6.85,8.72)$ & $(4.76,6.76,8.67)$ & $(4.88,6.88,8.79)$ & $(4.22,6.22,8.22)$ & $(3.93,5.93,7.93)$ \\
\hline
\end{tabular}

\section{Table 3}

Fuzzy average of input and output variables values in output-orientated CCR model

Using the method presented in fuzzy DEA section, triangular fuzzy numbers of input and output variables were converted to crisp numbers to be usable as input and output values in output-orientated CCR model and Andersen-Petersen model. The results are given in Table 4. In this study, the Outputorientated CCR model was used to increase the customer satisfaction index. In output-orientated CCR model the objective function value is more than or equal to 1 . If the objective value is 1 , it indicates the efficiency of studied unit and if the objective function is more than 1 , it indicates the inefficiency of the unit. Data obtained from Table 4, was inserted to output-orientated CCR model without any default and with the same weights. GAMS software was used for solving the model and the results are given in Table 5 . 
Table 4

Crisp values output-orientated CCR model

\begin{tabular}{lcccccc}
\hline Bank & $\begin{array}{c}\text { Perceived quality } \\
\text { input variable }\end{array}$ & $\begin{array}{c}\text { customer expectations } \\
\text { input variable }\end{array}$ & $\begin{array}{c}\text { Image } \\
\text { input variable }\end{array}$ & $\begin{array}{c}\text { perceived value } \\
\text { input variable }\end{array}$ & $\begin{array}{c}\text { customer satisfaction } \\
\text { input variable }\end{array}$ & $\begin{array}{c}\text { customer loyalty } \\
\text { input variable }\end{array}$ \\
\hline Pasargad bank & 6.70 & 7.07 & 7.07 & 6.55 & 7.87 \\
Ansar bank & 5.73 & 6.14 & 6.11 & 6.07 & 7.36 \\
Parsian bank & 7.00 & 6.91 & 7.28 & 6.80 & 7.07 \\
Saman bank & 6.90 & 6.61 & 6.45 & 6.58 & 7.85 \\
Shahr bank & 6.78 & 6.79 & 6.69 & 6.18 & 6.07 \\
Eghtesad-Novin & 6.68 & 6.60 & 6.75 & 6.62 & 6.10 \\
Sarmayeh bank & 7.09 & 7.37 & 7.30 & 7.10 & 6.83 \\
Tose'e bank & 6.94 & 6.82 & 6.74 & 6.86 & 6.24 \\
\hline
\end{tabular}

Table 5

Efficiency values associated with customer satisfaction index, Output-orientated CCR model

\begin{tabular}{|c|c|c|c|}
\hline Bank & CCR- Efficiency & LAMBDA & Efficiency \\
\hline Pasargad bank & 1.00000 & $\mathrm{~L} 1=1.0000$ & Efficiency \\
\hline Ansar bank & 1.00000 & $\mathrm{~L} 2=1.0000$ & Efficiency \\
\hline Parsian bank & 1.16112 & $\mathrm{~L} 1=0.0916 \quad \mathrm{~L} 2=0.7001 \quad \mathrm{~L} 4=0.2966$ & Inefficiency \\
\hline Saman bank & 1.00000 & $\mathrm{~L} 4=1.0000$ & Efficiency \\
\hline Shahr bank & 1.19403 & $\mathrm{~L} 1=0.9435$ & Inefficiency \\
\hline Eghtesad-Novin bank & 1.22359 & $\mathrm{~L} 2=0.3225 \quad \mathrm{~L} 4=0.6996$ & Inefficiency \\
\hline Sarmayeh bank & 1.24467 & $\mathrm{~L} 1=0.3868 \quad \mathrm{~L} 2=0.5141 \quad \mathrm{~L} 4=0.2201$ & Inefficiency \\
\hline Tose'e bank & 1.30977 & $\mathrm{~L} 2=0.6878 \quad \mathrm{~L} 4=0.3925$ & Inefficiency \\
\hline
\end{tabular}

In Table 5, the results of customer satisfaction index efficiency are shown. According to above results, the efficiency related to internet customer satisfaction index of Saman, Pasargad and Ansar banks is equal to 1 , which indicates that their web sites are efficient in terms of customer satisfaction index. Among these banks, Tose'e bank has the minimum efficiency. Output-orientated AndersenPetersen model is used for ranking the efficient units.

In output-orientated Andersen-Petersen model, the efficient units with objective function value of less than 1, will be ranked higher than the other units. Regarding to the result shown in table 5, the number of determined efficient units is 3. So, in output-orientated Andersen-Petersen model, these units show the efficiency border and the other units can be assessed according to this border. GAMS software is used to solve this model and the results of the customer satisfaction index efficiency from e-banking are shown in Table 6.

Table 6

Ranking of customer satisfaction index efficiency, output-orientated AP model

\begin{tabular}{lcc}
\hline Bank & AP- Efficiency & Ranking \\
\hline Pasargad Bank & 0.9728 & 3 \\
Ansar Bank & 0.9144 & 1 \\
Parsian Bank & 1.1611 & 4 \\
Saman Bank & 0.9638 & 2 \\
Shahr Bank & 1.1940 & 5 \\
Eghtesad-Novin Bank & 1.2236 & 6 \\
Sarmayeh Bank & 1.2447 & 7 \\
Tose'e Bank & 1.3098 & 8 \\
\hline
\end{tabular}

According to Table 6, Ansar bank has the most efficient web site in terms of customer satisfaction index from e-banking. Pasargad and Saman banks are in the second and third places, respectively. In today's competitive world, banks need to increase their understanding of customer approach to achieve their goals. Regarding the above results, Parsian, Sarmayeh, Shahr and Tose'e banks should focus more on customer satisfaction and loyalty. Since the perceived quality variable is one of the most important and effective factors for customer satisfaction and loyalty variables, continuous improving of service quality and comparative tools of provided service with competitors' service and increasing the structural attraction of web site in terms of prestigious capabilities should be considered in strategic programs and policies of these banks. In e-banking services, a great part of services have the value-creating aspect, especially for the new customers. The greater the Customer's 
perception about the uniqueness of new services, the greater is their satisfaction with e-banking service and customer loyalty. The augmentation of guide tools for searching the services, the ease of using the provided services for customer and the users' trust on server and services result in increasing of customer satisfaction with e-banking services and customer loyalty, then, lead to increase of efficiency and ultimately efficiency of web site in terms of customer satisfaction index with e-banking services. With respect to obtained results from output-orientated AP model, the banks with inefficient web sites in terms of customer satisfaction index should follow the model of banks with efficient web sites and should try to offer better services in their web sites. The banks with efficient web sites in terms of customer satisfaction index should try to improve, diversify and develop their services which can lead to an increase in their web site efficiency ranking compared with other web sites in terms of customer satisfaction index.

\section{Conclusions}

\subsection{Main findings}

Regarding to the growing trend of e-commerce, what can make a corporation prominent in the competitive market, is gaining competitive advantages in this field. Therefore, companies need banking operations for transferring financial resources-banking, which has a fundamental role in ecommerce. Nowadays, e-banking is an inseparable part of e-commerce and has an important role in its implementation. Today, many banks around the world use the electronic services as a tool for market development, improving the customer services, cost reduction and promotion of productivity. Customer satisfaction is one of the most important issues in e-banking. Modern management philosophies introduced the customer satisfaction as a base standard for each business's efficiency. The first step in evaluating the efficiency is selection of an appropriate evaluation model for dimensions based on which the decision makers can evaluate their units. This paper focuses on how to evaluate the customer satisfaction through studying the effective factors involved in customers' satisfaction with electronic services. Data Envelopment Analysis (DEA) is a management method which measures each unit's relative efficiency (DMU) and provides management solutions. The main goal of this study is evaluating and ranking the customer's satisfaction index efficiency among the internet customers of 8 Iranian banks using the fuzzy DEA model. For using the fuzzy DEA model to determine the customer satisfaction index efficiency in e-banking, perceived quality, image, customer expectations and perceived value were considered as input variables of the model, while customer satisfaction and customer loyalty were considered as output variables. The main idea for determining the customer satisfaction index efficiency is based on fuzzy DEA model conversion to a linear programming model by $\alpha$-cut method. In this way, the responses obtained from fuzzy model solution are more precise than the classic models. One of the characteristics of this paper is studying simultaneously the fuzzy set theory and traditional DEA method in one model and studying the relation between them. According to results obtained from output-orientated CCR model, Saman, Pasargad and Ansar banks are totally efficient or on the efficiency border in terms of internet customer satisfaction index and Tose'e bank has the minimum efficiency. One of the characteristics of DEA method is ranking the efficient decision making units (DMUs). Results of output-orientated AP model show that Ansar bank has the most effective web site in terms of customer satisfaction index, Pasargad and Saman banks are in the second and third places, respectively. Also, it seems that the fuzzy DEA model in terms of customer satisfaction index evaluation in e-banking is an appropriate model because a model characteristic is to be precise and applicable to similar settings. Electronic services to customers have always been important. But today's customers have more choices compared to customers in the past decade. Illustrious electronic services should be specified by customer demands and expectations. If in the view of supplier, electronic services are very interesting, but in practice they fail to provide customer satisfaction, these services are not considered outstanding. By an overall study of the customer satisfaction index, it can be concluded that internet banking in these 8 banks gives better tools for decision making in internet baking and forecasts the level necessary to eliminate deficiencies and needs in the educational programs, research and services 
provided especially in the field of e-banking. Comparison of the status of each bank with the same bank in terms of performance indicates that in order to improve efficiency, a comprehensive planning and various types of criteria are required. In some cases, it may take years to achieve the benefits of efficiency. Therefore, banks should not feel despondent and desperate at the beginning stages of experiencing performance improvement programs. Careful analysis, review and remedial action will lead the efficiency programs to the right direction. According to findings of this article, it seems that the fuzzy DEA model in terms of customer satisfaction index evaluation in e-banking is an appropriate model because one of the most significant characteristics of a model is its preciseness and applicability.

\subsection{Future research}

It is suggested to formulate a series of criteria and standards in terms of effective factors in customer satisfaction index efficiency in e-banking by using how it would be possible to measure and to determine the efficiency changes. The methodology used in this research is easily applicable to organizations which have internet customers. These organizations can identify and rank the effective factors in customer satisfaction index efficiency using the decision models and considering their situation. Regarding the limitations of output-orientated CCR model, it is suggested to future researchers to use the other DEA models and compare the results with results obtained from outputorientated CCR model. Since fuzzy DEA model is a numerical and mathematical technique, so, the measurements errors can cause remarkable changes in results. Therefore, after identifying efficient decision making units (DMUs), data needs to be controlled again to ensure its accuracy.

\section{Acknowledgements}

We would like to acknowledge the financial support provided by Ansar Bank, the Iranian private bank.

\section{References}

Andersen, P., \& Petersen, N. C. (1993). A procedure for ranking efficient units in data envelopment analysis. Management science 39 (10):1261-1264.

Anderson, R. E., \& S. S. Srinivasan. (2003). E-satisfaction and e-loyalty: A contingency framework. Psychology \& Marketing, 20(2),123-138.

Bai, B., Law, R., \& Wen, I. (2008). The impact of website quality on customer satisfaction and purchase intentions: Evidence from Chinese online visitors. International Journal of Hospitality Management, 27(3), 391-402.

Banker, R. D., Charnes, A., \& Cooper, W.W. (1984). Some models for estimating technical and scale inefficiencies in data envelopment analysis. Management science, 30(9),1078-1092.

Barry, J., \& Terry, T. S. (2008). Empirical study of relationship value in industrial services. Journal of Business \& Industrial Marketing, 23(4), 228-241.

Blanchard, R., \& Galloway, R. (1994). Quality in retail banking. International Journal of Service Industry Management, 5(4), 5-23.

Casado-Díaz, A. B., \& Nicolau-Gonzálbez, J.L. (2009). Explaining consumer complaining behaviour in double deviation scenarios: the banking services. The Service Industries Journal, 29 (12), 16591668.

Charnes, A., Cooper, W. W., \& Rhodes, E. (1978). Measuring the efficiency of decision making units. European Journal of Operational Research, 2(6), 429-444.

Cheung, C. M., \& Lee, M. K. (2005). Consumer satisfaction with internet shopping: a research framework and propositions for future research. Paper read at Proceedings of the 7th international conference on Electronic commerce.

Ciavolino, E., \& Dahlgaard, J. J. (2007). ECSI-customer satisfaction modelling and analysis: a case study. Total Quality Management, 18(5), 545-554. 
Cooper, W. W., Seiford, L. M., \& Tone, K. (2005). Introduction to data envelopment analysis and its uses: with DEA-solver software and references.

Cyr, D., Kindra, G. S., \& Dash, S. (2008). Web site design, trust, satisfaction and e-loyalty: the Indian experience. Online Information Review, 32(6), 773-790.

Davis-Sramek, B., Droge, C., Mentzer, J. T., \& Myers, M. B. (2009). Creating commitment and loyalty behavior among retailers: what are the roles of service quality and satisfaction?. Journal of the Academy of Marketing Science, 37(4), 440-454.

Farquhar, J. D., \& Panther, T. (2008). Acquiring and retaining customers in UK banks: An exploratory study. Journal of Retailing and Consumer Services, 15(1), 9-21.

Feicheng, M., Tao, L., \& Guoliang, Z. (2009). A conceptual model of e-commerce sale service for manufacturing industry. International Conference on E-Business and Information System Security. EBISS'09.

Finn, A. (2011). Investigating the non-linear effects of e-service quality dimensions on customer satisfaction. Journal of Retailing and Consumer Services, 18(1), 27-37.

Flint, D. J., Blocker, C.P., \& Boutin, P.J. ( 2011). Customer value anticipation, customer satisfaction and loyalty: An empirical examination. Industrial Marketing Management, 40(2), 219-230.

Gazor, H., B. Nemati, A. Ehsani, and K. Ameleh. (2012). Analyzing effects of service encounter quality on customer satisfaction in banking industry. Management Science Letters, 2(3), 859-868.

Grigoroudis, E., Nikolopoulou, G., \& Zopounidis, C. (2008). Customer satisfaction barometers and economic development: An explorative ordinal regression analysis. Total Quality Management, 19 (5), 441-460.

Guo, P., \& Tanaka, H. (2001). Fuzzy DEA: a perceptual evaluation method. Fuzzy sets and systems, $119(1), 149-160$.

Hsiao, M.-H. (2009). Shopping mode choice: Physical store shopping versus e-shopping. Transportation Research Part E: Logistics and Transportation Review, 45(1), 86-95.

Kristensen, K., Martensen, A., \& Gronholdt, L. (2000). Customer satisfaction measurement at Post Denmark: results of application of the European Customer Satisfaction Index methodology. Total Quality Management, 11(7), 1007-1015.

Lee, M. C., \& Hwan, I. (2005). Relationships among service quality, customer satisfaction and profitability in the Taiwanese banking industry. International Journal of Management, 22(4), 635.

Li, D.-F. (2012). A fast approach to compute fuzzy values of matrix games with payoffs of triangular fuzzy numbers. European Journal of Operational Research, 223(2), 421-429.

Liu, X., Zeng, X., Xu, Y., \& Koehl, L. (2008). A fuzzy model of customer satisfaction index in ecommerce. Mathematics and Computers in Simulation, 77(5), 512-521.

Marimon, F., Petnji Yaya, L. H., \& Casadesus Fa, M. (2012). Impact of e-Quality and service recovery on loyalty: A study of e-banking in Spain. Total Quality Management \& Business Excellence, 23(7-8), 769-787.

Mihelis, G., Grigoroudis, E., Siskos, Y., Politis, Y., \& Malandrakis, Y. (2001). Customer satisfaction measurement in the private bank sector. European Journal of Operational Research, 130(2), 347360.

Molina, A., Martín-Consuegra, D., \& Esteban, À. (2007). Relational benefits and customer satisfaction in retail banking. International Journal of Bank Marketing, 25(4), 253-271.

Oliver, R. L. (1980). A cognitive model of the antecedents and consequences of satisfaction decisions. Journal of marketing research, 460-469.

Petridou, E., Spathis, C., Glaveli, N., \& Liassides, C. (2007). Bank service quality: empirical evidence from Greek and Bulgarian retail customers. International Journal of Quality \& Reliability Management, 24(6), 568-585.

Poddar, A., Donthu, N., \& Wei, Y. (2009). Web site customer orientations, Web site quality, and purchase intentions: The role of Web site personality. Journal of Business Research, 62(4), 441450 . 
Razak, M. R. A., Chong, S. C., \& Lin, B. (2007). Service quality of a local Malaysian bank: customers' expectations, perceptions, satisfaction and loyalty. International Journal of Services and Standards, 3(1), 18-38.

Reynolds, K. L., and L. C. Harris. (2009). Dysfunctional customer behavior severity: an empirical examination. Journal of retailing, 85(3), 321-335.

Saati, S., Zarafat Angiz, M., Memariani, A., \& Jahanshahloo, G. (2001). A model for ranking decision making units in data envelopment analysis. Ricerca Operativa, 31(97), 47-59.

Saati, S. M., Memariani, A., \& Jahanshahloo, G. (2002). Efficiency analysis and ranking of DMUs with fuzzy data. Fuzzy Optimization and Decision Making, 1(3), 255-267.

Salehi, M., \& Alipour, M. (2010). E-banking in emerging economy: empirical evidence of Iran. International Journal of Economics and Finance, 2(1), 201.

Sánchez-Fernández, R., \& Iniesta-Bonillo, M. (2009). Efficiency and quality as economic dimensions of perceived value: Conceptualization, measurement, and effect on satisfaction. Journal of Retailing and Consumer Services, 16(6), 425-433.

Sengupta, J. K. (1992). A fuzzy systems approach in data envelopment analysis. Computers \& Mathematics with Applications, 24(8), 259-266.

$\mathrm{Su}, \mathrm{A}$. Y.-L. (2004). Customer satisfaction measurement practice in Taiwan hotels. International Journal of Hospitality Management, 23(4), 397-408.

Szymanski, D. M., \& Hise, R.T.. (2000). E-satisfaction: an initial examination. Journal of retailing 76(3), 309-322.

Talluri, S. (2000). Data envelopment analysis: models and extensions. Decision Line, 31(3), 8-11.

Vasudevan, H., Gaur, S. S., \& Shinde, R. K. (2006). Relational switching costs, satisfaction and commitment: a study in the Indian manufacturing context. Asia Pacific Journal of Marketing and Logistics, 18(4), 342-353.

Wang, Y.-S., Yeh, C.-H., \& Liao, Y.-W. (2012). What drives purchase intention in the context of online content services? The moderating role of ethical self-efficacy for online piracy. International Journal of Information Management.

Wen, M., \& Li, H. (2009). Fuzzy data envelopment analysis (DEA): Model and ranking method. Journal of Computational and Applied Mathematics, 223 (2), 872-878.

Wirtz, J. (2003). Halo in customer satisfaction measures: The role of purpose of rating, number of attributes and customer involvement. International Journal of Service Industry Management, 14 (1), 96-119.

Yang, Z., \& Fang, X. (2004). Online service quality dimensions and their relationships with satisfaction: a content analysis of customer reviews of securities brokerage services. International Journal of Service Industry Management, 15(3), 302-326.

Zadeh, L. A. (1965). Fuzzy sets. Information and control, 8(3), 338-353.

Zeithaml, V. A., Bitner, M. J., \& Gremier, D.D. (2006). Service Marketing: Integrating Customer Focus Across The Firm-4/E.

Zerafat Angiz L. M., Emrouznejad, A., \& Mustafa, A. (2012). Fuzzy data envelopment analysis: A discrete approach. Expert Systems with Applications,39(3), 2263-2269.

Zimmermann, H. J. (2010). Fuzzy set theory. Wiley Interdisciplinary Reviews: Computational Statistics, 2(3), 317-332. 